\title{
African urbanims: Reinterpreting the marks of the church
}

\author{
Naudé, Piet \\ Stellenbosch University \\ Piet.Naude@usb.ac.za
}

\begin{abstract}
$^{1}$
This essay presents a broad analysis of African "cityness" and brings this analysis in relation to an ecumenical interpretation of the marks of the church. The aim is to construct an "urban ecclesiology" where the realities of African cities influence our understanding of the church, and where - in turn - the marks of the church provides some pointers to a life of community, justice and fulfilment in the city.
\end{abstract}

\section{Keywords}

Ecclesiology, urban theology, marks of the church, Africa cityness, and urbanisms

"Cities are the greatest and most complex of human art forms" (Graham Ward: The politics of discipleship, 2009: 207)

"To be sure, African cities and towns are marked by profound crisis.... The shanty city is by and large the real African city" (Edgar Pieterse: Grasping the unknowable: Coming to grips with African urbanisms, 2013: 21)

"If we can really hope for the kingdom of God, then we can also endure the Church in its pettiness" (Karl Barth: Dogmatics in outline, 1949:148)

1 I gratefully acknowledge the fruitful discussions held in Gothenburg and Port Elizabeth by the small team working on urban theology, as well as the critical comments by the two reviewers of the initial draft. 


\section{The task at hand...}

This essay does not focus primarily on the theological meaning of cities per se as expressed in the question: "What kind of theological statement does the city make?" The focus is rather on the reciprocal relation between urban realities and ecclesiology. ${ }^{2}$ The questions are: "What are the ecclesiological implications of living in the city? And what could - conversely - the impact be of ecclesiology on urban living?" This is therefore an attempt to develop an "urban ecclesiology" as a sub-set of a broader "urban theology" where the traditional loci of systematic theology are re-framed in the radically altered context of intensifying urbanization (the process of people moving into cities) and urbanism (the state of living in cities).

Like with all theological projects that attempt to bring the gospel into relation with a specific context, the hermeneutical task of an "urban ecclesiology" requires attention for at least the following:

1. A multi-disciplinary interpretation of "urbanization", "urbanism" and "cityness" to answer questions like: What are the salient features of the urban context? What are the signs of the time configured by the realities of urbanism? And how are these signs to be read? ${ }^{3}$

2. A re-interpretation of the ecumenical marks of the church to answer questions like: What do Scripture and tradition via the notae ecclesia tell us about the church?" And how should these marks be understood in the context of urban realities today?

2 A noteworthy example of such a task is the (controversial) 1985 report by the Commission on Urban Priority Areas of the Church of England, published as Faith in the city. A call to action by church and nation. In chapter 1 an environmental analysis of inner-city areas are done (see pp. 3-26) whilst chapter 3 is devoted to theological priorities, including a discussion of the tradition of Christian social thought (see pp. 4772). A follow-up report appeared in 2006 as Faithful cities, commemorating the initial report after 20 years.

3 That this interpretative task is a highly contested space, emerges - for example - from the "African urbanism initiative" housed in the African Centre for Cities (ACC, founded in 2008) at the University of Cape Town, South Africa. The volume, Rogue urbanism, is - for example - an attempt by ACC to bring scholars from a variety of disciplines (urbanists, architects, artists, novelists, anthropologists, development economists) from across Africa together. The aim is to question the invisible assumptions and policy directives of Western, developmentalist approaches that view Africa as an incomplete project of modernity toward understanding "the rich, complex and indeterminate dynamics of 'cityness' in urban Africa..." (12) and advancing "a thick analytical account of African cityness..."(13).

4 As theologians reading this essay will know, the interpretation of the "marks" of the church has a long and rich history, marked by a plurality of views as different traditions 
3. A re-imagination of both the church in the city and of the city itself toward a more humanizing and just world, setting up signs that are pointers towards an eschatological hetero-polis.

It must be stated clearly: Situations differ quite radically and to talk about "the church" in "the city" somewhere "in Africa" invariably leads to gross generalizations. To provide some focus, this essay will for the most part consciously reflect on the church contextualised in the realities of (South) African cities.

Even this "focus" is unsatisfactory as it cannot do justice to the specificity of distinctly different case studies which illustrate both the extinction and the flourishing of churches in cities on the African continent. Even the word "church" has different meanings: the worshipping local congregation; a specific denomination; individual Christians living their faith in the ordinary course of events; and referring to the widest ecumenical conception of the institutional "church" (see Smit 2008:70-71). For the most part the discussion below will refer to the church as institution being present at local urban level.

Underlying the discussion is obviously one's own theological assumptions and social location. I write from the perspective of the (white) middle class with all its limitations. The views expressed in this essay flow from a socially engaged, confessing, Reformed tradition with a conscious ecumenical orientation, for the most part shaped by the history of the church in South Africa before and after the democratic transition of 1994.

\section{The marks of "cityness" in Africa}

Drawing on the recent work of Edgar Pieterse (2013a and 2013b), professor of Architecture and urban policy at the University of Cape Town, the following broad factors mark urbanization in Africa:

First. The continent is still at the beginning of a transition from rural to urban with around $40 \%$ of people living in cities. But the trend is unmistaken: Africa manifests the fastest annual rate of urbanization

(Orthodox, Catholic, Protestant, Pentecostal) hold different emphases. For the sake of brevity, I will "anchor" my exposition below in Confessing the one faith (1991), the ecumenical consensus captured in the WCC project on a contemporary interpretation if the Nicene-Constantinopolitan creed, and complement this with aspects drawn from the Reformed confessional tradition. 
at $3.31 \%$ with UN-HABITAT projecting in 2008 an urban population of $750 \mathrm{~m}$ people by $2030 .^{5}$

Second. Urbanites in Africa reside in smaller cities of below $0.5 \mathrm{~m}$ people with only $6 \%$ living in cities exceeding $10 \mathrm{~m}$ people. ${ }^{6}$ What does emerge, is "city-region zones" that link together cities in regional corridors, creating greater urban density.

Third. Almost all current and future growth in African cities will be in the form of slum growth. The prevalence of slums - marked by the absence of basic services like water, sanitation and electricity - stems from governments who judge the provision of such services as incentives for urbanization which is by itself seen as undesirable. As a consequence, the investment in urban infrastructure has in fact declined from $4 \%$ of GDP in 1980 to less than $2 \%$ by 2000 (Pieterse 2013a; see figure on p. 21).

Pieterse concludes: "Whatever way one looks at the phenomenon of urbanization in Africa, it is impossible not be alarmed by the cumulative dynamism of exclusion, impoverishment and deepening inequality that is in stark evidence" (2013a: 24, his emphasis) This give rise to "the need to theorise African urbanism from the perspective of ordinary people who live in these slum conditions" (2013a: 23).

\section{The marks of the church}

There is ecumenical consensus in the creeds and confessions that the church is a creation of the Tri-une God (Nicea, Apostolicum, Heidelberger

5 In the period 2000 - 2013 all African countries - except two of the smallest, i.e. Swaziland and Mauritius - experienced a marked growth in urban population with growth as high as $42.8 \%$ (Rwanda), 35.5\% (Uganda), 26.1\% (Egypt) 23.9\% (Angola), 23.8\% (Tanzania), 22.9\% (Algeria) and 20\% (Nigeria) (see IRR 2014: 33). This migration places huge demands on urban planning and infrastructure development, resulting in the growth of informal and slum areas.

6 By 2011, there were two cities with more than 10m inhabitants in Africa, namely Lagos $(11.2 \mathrm{~m})$ and Cairo $(11.1 \mathrm{~m})$

7 It is notoriously difficult to get standard definitions of "slums" or determine the number of people actually living in such conditions as national policies vary across Africa as to the classification and legal status of dwellings as "formal", "informal", "traditional" or "squatter" residents (IRR 2014: 622-625). GIS technologies are in most cases the only way in which census data can be compiled. 
Catechism ${ }^{8}$ ), and more specifically an integral part of the third article on the Holy Spirit. ${ }^{9}$ The recent Belhar Confession ${ }^{10}$ (1986, article 1) states that it is "the tri-une God, Father, Son and Holy Spirit" who "gathers, protects and cares for his Church by his Word and Spirit, as He has done since the beginning of the world and will do to the end".

The marks of the church as one, holy, catholic and apostolic church "is the richest form of confessing the church in the history of the early Christian creeds" (WCC 1991: paragraph 220). The marks are not merely descriptive in nature - they are at the same time normative challenges to faith communities to reflect and realize the implicit ideals contained in these marks.

The marks of the church may serve as basis for an urban ecclesiology where the hermeneutical tasks outlined above are brought together in one movement of interpreting the realities of the city, re-reading the marks of the church, and constructing the reciprocal dynamics between "church" and "city" which transforms both beyond their current state.

In this essay - with far too little space to do justice to a much bigger task an attempt is made to accomplish this "reconstructing" hermeneutical task as follows:

- Reconstructing identities amidst a loss of community and alienated senses of "difference" may be fostered via a reinterpretation of the unity of the church.

- Re-constructing values amidst the pressures of consumerism, violence and a corrupt/incapable state may be addressed via a reinterpretation of the holiness of the church.

- Reconstructing a sense of historical continuity and living the global in the local amidst the homogenizing and disoriented power of globalism may be enabled by a reinterpretation of the catholicity of the church.

8 See Question and Answer 54.

9 "It prevents the Church from appearing as an isolated object of faith". WCC 1991: paragraph 219.

10 For the text of the confession, go to www.urcsa.org and for an elaborate explication and discussion, read Cloete and Smit 1984, and Naudé 2010. 
- Reconstructing vulnerability and marginalization amidst concentrated urban a-symmetries of gender, class, education, race and health may be informed by a reinterpretation of the apostolicity of the church.

\subsection{The one church}

(John 14, 1 Cor. 14, Eph. 4) $)^{11}$

Cities are places of promise for a better life because the concentration of people enables - via economies of scale - the advancement of services, diversification of labour, and sophisticated forms of cooperation for the individual and public good. But many experience the city as a place of broken promises where the dream of a "cooperative community" is replaced by the reality of social atomism, self-centred competitiveness with its resultant ambiguous experiences of intense loneliness whilst living among thousands and even millions of other people. Pieterse - drawing on the work of Chabal (2009) - talks about urbanization involving the "crumbling of former familial and traditional socialization networks" (2013a: 25-26). Although re-socialization does occur, a marked group insularity persists, and the communitarian possibilities of city life remain for many only unfulfilled expectations.

In the context of Africa, life in the city often leads to a corruption of ubuntu $^{12}$ from its universal intentions (I am because we are) to become closed circles of tribal, political, class, and neighbourhood loyalties.

This retreat into in-humanity is markedly illustrated by the intermittent attacks ${ }^{13}$ on foreigners (makwerekere) where - in the face of competition for labour, informal trading and scarce resources - shops are burnt down and people are killed, shattering the dream of Ubuntu. Instead of living

11 The Biblical references here and below are simply listed and not discussed in detail. They serve as pointers to the most common textual foundations for the marks of the church.

12 The notion of $u b u n t u$ was introduced into academic debate via John Mbiti's discussion of African kinship in his African religions and philosophy (1969). For an exposition and critical discussion, read Smit 2007:119 and Naude 2011.

13 At the time of finalising this paper (April 2015), deadly violence against African foreigners started in the townships of Durban and spread to other urban areas in South Africa, inter alia spurred on by the xenophobic remarks by the King Zwelithini of the Zulu kingdom. There are public outcries and churches currently play a definite role in witnessing against xenophobia. 
a cooperative life together, whilst retaining and in fact claiming the right and freedom to be different, one finds the construction of "life-worlds" which "embrace actions, interactions and meanings, and are identified with specific socio-graphical spaces..." (Long 2001: 241). In this manner, self-understanding is often maintained along ethnic and nationalistic lines. It is only in the naming and subsequent exclusion of "the other" that there remains a sense of (diminished) community.

The unity of the church is "grounded in the communion of the Trinity" (WCC 1991: paragraph 225) and this unity is not only a spiritual ${ }^{14}$ matter - it requires embodiment. The impulse behind the broader ecumenical movement of the $20^{\text {th }}$ century as well as the specific contours of the church struggle in South Africa ${ }^{15}$, always insisted that the unity of faith should be expressed in institutional, visible and outward form. The Scriptures "point toward this visible unity which can be fully actualised only in one Eucharistic communion” (WCC 1991: paragraph 238).

Where the church in a region or at local level not only fails to embody this unity, but in fact becomes mere mirrors or replicas of societal divisions - endorsing them from a theological perspective and intensify them by providing implicit or even explicit moral justifications for disunity on the basis of nationality, language, race or class - she denies the very basis of her own existence as image of the one God.

In the city, the disunity of the church is amplified in the ambiguous synergy between two forces: Urban divisions and insular closed identities find a spiritual home in ethnically defined churches; and (second) the fast spreading of African Independent and Pentecostal type churches - specifically in poor areas - show a lack of ecumenical sensibility and fractious leader-centred-ness which leads to a proliferation of the

14 Much has been made of the spiritual, invisible, and eschatological unity of the church. In the South African context, these were powerful tools in the hands of those who defended racially separated churches" We need not actually be one, as we are already spiritually one", was the argument. "It is best not to apply the idea of invisibility to the Church", writes Karl Barth as "we are all inclined to slip away in the direction of a civitas platonica or some sort of Cloud-cuckooland, in which Christians are united inwardly and invisible, while the visible Church is devalued" (Barth 1949:142).

15 From an ecumenical perspective on unity, see Edmund Schlink's major contribution in his Ökumenische Dogmatik (original 1983; 2005:700-708), and for a classic work on South Africa, read John de Gruchy: The church struggle in South Africa (1979). 
institutional church itself. ${ }^{16}$ If one adds urban apartheid, the legally enforced race-based suburbs and townships still lingering today in South Africa, the challenge for the visible, institutional unity of the church becomes even more pronounced. ${ }^{17}$

From Scripture we learn about the people of God as eschatological "exemplar community"; of being a sign of the peaceable kingdom where natural contradictions and enmities - the lion and the lamb, the child and the serpent - are united by the knowledge of the Lord (Is. 11). We learn about the first faith community, consisting of people speaking many languages and including both rich and poor, united by the outpouring of the Holy Spirit and sharing in bread, prayer and praise (Acts 2). We learn about the church called to embody an egalitarian vision where Greek/Jew, lord/slave and man/woman are united via the one faith in Christ Jesus (Gal. 3).

In is exactly in the city where differences of all kinds reduce the span and quality of human community that the church is called to visible unity. This calling is to form exemplar egalitarian communities, witnessing to the reality of reconciled differences. If the church fails in this calling, divided religious loyalties are simply extensions of a community already at war with itself.

\subsection{The holy church}

(Lev. 11, 1 Cor. 1, I Peter 1, Phil. 2)

Urbanization as a process, describing the movement of people from rural communities to urban and semi-urban spaces, is undergirded by a significant re-orientation of values. For the most part the city's attraction as economic power-house carries with it a significant consumer density where "everything has a price but nothing has value" (Oscar Wilde). There is a radical anthropological reduction of people to customers and

16 Whilst one may question this development of "dis-unity" from a theological perspective, the difficult question is whether Christian splinter-groups with a strong focus on healing and prosperity that spring up/vanish are not providing a social network, opening up new sites of belonging, albeit temporary ones?

17 The WCC report (paragraph 226) emphasises: "All local churches and their members should enjoy unity in the same faith and life, reflecting the communion of father, Son and Holy Spirit... However, as long as ecclesial divisions exist, the presence of the one Church of Christ continues to be diminished in each of them." 
consumers, pitting them against one another as competitors in the race for (mostly temporary) jobs and a livelihood based on the ability to enter the system of monetary exchange.

African urbanites are perpetual deal-makers, ${ }^{18}$ writes Pieterse, involving themselves in "elaborate and intricate processes whereby agreements are forged to cooperate in order to achieve some modest access to cash, information favours, goods and the possibility of a reciprocal turn in the future..." (2013a: 33). This endemic deal-making is a deeply fragile process as there are many actors and forces that can ruin a deal even before it is fully hatched, and this erodes the value of trust underlying the barter economy prevalent in rural areas.

A second value-shift relates to violence. Pieterse, referring to the data on conflict-related deaths, speaks about routinized violence as dominating urban life in Africa: "'the everyday' or mundane normalcy, is profoundly scarred by structural and symbolic violence, which in turn produces an acute level of social violence that over-determines familial and domestic relations" (2013a:28).

In the townships and slum areas of most African mega-cities, there is a constant confrontation with various forms of violence: Psychological (little or no assistance to make the transition to urban life), aesthetical (chaotic urbanization with shanty towns and informal settlements confronting any sense of structure or beauty, often creating ecological wastelands as well); physical (high levels of violence against women and children with rampant serious and petty crime) and structural violence (lack of basic infrastructure and services like water, health, sanitation, education and transport).

If one couples these traits of precarious deal-making and violence with high levels of corruption at local government level - reversing values of honesty and transparency and accountability - the immersion into African city life indeed constitutes a clash of values. Competing values make contradictory claims to what defines the dignity of a human person and what counts as "right" and "good", if it is at all possible to make such claims amidst a morally ambiguous urbanity.

18 Pieterse suggests that the very term "economy" and the distinction between "formal" and "informal" are virtually meaningless and redundant "because most of the city is the consequence of hybrid economic practices..." (Pieterse 2013b:13, see also page 28). 
To call the church a "holy" community means - inter alia - that the church is "being set apart by God who is holy and sanctifies it by the word and sacraments." The church, furthermore, is continually justified and sanctified by Christ, and is also holy because of the "holy acts" it performs (WCC 1991: paragraph 239). But in Scripture, the confessions, and the broad Christian tradition, being set apart by and for God always implied service to others, including the ecological cosmos as created by God. ${ }^{19}$

This servant mission - imitating Christ's incarnation (Phil 2) - includes the people of God as a moral community based on the precepts of the law and values of the gospel as reinterpreted in every age. The church is a truthseeking community and does not only have a social ethic - it is that social ethic (Hauerwas). Via "internal" preaching, catechesis and faith-formation the local church provides for Christians a values-framework from which they are able to traverse the ambiguous realities of the city, contributing to the humanization of this very city via small acts of care, trust, honesty and uprightness. $^{20}$

Our tradition teaches us that no matter how contemporary cities are interpreted - late-modern or post-modern, secular or post-secular, spiritual or a-theological - the holiness of the church is best expressed via incarnational discipleship, rendering its service "for the salvation of mankind" (WCC:1991, paragraph 239). There are numerous examples of local churches in the informal settlements and townships that are beacons of hope by simply being there. They represent reference points of peace, justice, truth and - sometimes - physical refuge. ${ }^{21}$ The church as holy church is called to live the values of love for God and the other, and, where

19 See the strong sections on the responsibility of humanity in creation and the ethics of creation in paragraphs 84-89 of the WCC project (WCC 1991) which states that "the commission to rule over the world has been divorced, in a process of emancipation, from accountability to the Creator" (paragraph 85 ). There is an explicit rejection of any attempt to secure our future at expense of the world (WCC:1991, paragraph 276).

20 An interesting example of this is the Zionist Christian Church members who carry the church's emblem (a star or a dove) on their clothes. By carrying this sign, they pronounce honesty and character and often find employment based on this outward witness.

21 A very "public" case of until recently providing a home to Zimbabwean refugees, is the Central Methodist Church of Johannesburg, led at the time by Bishop Verryn. 
appropriate, prophetically ${ }^{22}$ to expose the falsehood of corruption, and being a key factor in peace-building amidst violent-prone and post-conflict communities. ${ }^{23}$

\subsection{The catholic church}

Ps 24, Is. 2, Rom. 8, Col. 1, Heb. 13:8

Moving to the city might be described as both a sign of and an immersion into globalism insofar as global cities are "the very hubs of globalisation" (Ward 2009:206). Whereas globalization is the process of creating a networked world most vividly expressed in economic and cultural exchange aided by the communication (virtual) revolution, globalism expresses the negative ideological fruits of this process in neo-liberal capitalism ("empire") and economic marginalization of Africa; the homogenizing power of Western culture, suppressing "indigenous" knowledge and art; and the reduction of a historical consciousness to living in a collapsed presence ${ }^{24}-$ all infused by the metaphysical power of a new grand narrative that obliterates and silences alternative views of the world. ${ }^{25}$

Let us turn our attention to the aspect of history only:

22 For a discussion on the value and limitations of prophetic discourse in dialogue with Gustafson's four modes of ethical discourse, read Naudé 2011.

23 Public marches against racism, against domestic violence, and against xenophobia are often led by church leaders, and churches have played an integral part in peace-building processes in post-conflict situations all over Africa, notably in South Africa, Rwanda, the DRC and South Sudan.

24 Ward makes a compelling case to argue for a close link between globalization and both secularization and Christian eschatology, leading to the formation of a myth or an illusion with powerful directing power: What we see is "detraditionalized religion, a religion without a past or future", emphasizing a living in the now, the present, the modo (Ward 2009: 105, 106).

25 The literature on globalisation is too vast to recite here. There are deep ideological and theological differences in the various assessments of globalization: For a more positive appraisal, see specifically the fourth volume in the God and globalization series by Max Stackhouse (Stackhouse 2007); and for a highly critical evaluation, see the two volumes on globalisation edited by Boesak and Hansen (2009 and 2010) published by the Beyers Naude Centre at Stellenbosch University. I have been particularly influenced by the following authors: Held et al (1999) on the history and description of globalization processes; Patel (2011) on a critique of global market fundamentalism; and Ward (2009) on the link between Christianity and globalization, and the implicit claim to transcendence and eschatological vision heralded by processes of globalization. 
The Jewish-Christian tradition was from the beginning infused with a "global" vision, both historically (via mission) and eschatologically (via a cosmic Christ who returns to create a new heaven and a new earth). Christianity itself played a major role in initiating the globalization process that marks modern human history from around 1500 onward, and the current rapid spread of Pentecostalism and Muslim fundamentalism are both expressions of and drivers for/against globalization processes.

It is therefore interesting to note that "catholicity" is included in the earliest creeds of the church. It was interpreted in relation to Christ with both an historical (in relation to the whole of history - past, present and future) and spatial (in relation to the whole world) dimension. The Confessing the one faith project says that the "catholic nature of the church is realized and expressed... among all peoples in space and time" (WCC 1991: paragraph 240).

Historical catholicity implies that the church here and now stands as prolongation of the church through the ages, on the cusp of the intersection between past, present and future. It represents a marked historical consciousness, held in tact by the confession that Christ is the same, yesterday and today, and for ever (Hebrews 13). The catholic church provides a space for both continuities and discontinuities. It is both a haven of stability (via symbols like the cross, the altar, the Scriptures and the confessions) and an uncomfortable source of instability, radically challenged by those very same symbols.

Spatial catholicity - quite often perverted by the link between political (colonial) power and the church - means that each local church is an expression of the church universal, and it expresses the missionary intention of the church to bring the gospel to the full oikoumene. This witness proceeds not in domination but in service, based on the faith conviction that "the earth belongs to the Lord" and that every creature is made by and for Christ (Col 1; John 1).

The story of God and his people is the rival narrative that challenges the perverse immanence and false claims to transcendence of the globalism story. The local faith community in the city provides strong senses of historical orientation, global community, and the ability to traverse the 
ambiguous space between the local and the global. Under situations of poverty and oppression, the consciousness that "we are not alone", that "we are part of a global faith community", serves as powerful source of hope and action. ${ }^{26}$

The church imbues the city with catholi-city.

\subsection{The apostolic church}

(Gen. 17, Jonah, Mt. 28, Acts 1)

There is no other human space where the a-symmetries of gender, class, education, race and health are so condensed than in the city. In fact, depending on which side of a street one lives, it can mean the difference between life and death. Inequalities of all kinds - income, wealth, access, participation - stand glaringly obvious next to one another in most of our African cities. One may call this a case of geographical justice: it all depends on where you are born or where you can afford or not afford to live.

Yes, cities are indeed also places of economic opportunity and growth, and millions all over the world have benefitted and are benefitting from urbanization. But cities are at the same time places of destitute. If one assesses the situation of $60 \%$ of African urbanites living in slums, "we must acknowledge their incessant efforts to find ways of breaking through the numbness that stems from having to carve out an existence at the brutal end of daily life framed by routine processes of exclusion, exploitation and discrimination - processes that demand a stylised resignation to one's fate" (Pieterse 2013a:31). ${ }^{27}$

This scramble for survival is markedly more visible in urban slums that in non-urban or rural settings where such socio-economic conditions are more dispersed, and for the most part embedded in a communitarian sense of reciprocal care. (One should, though, not idealise the realities of rural living where especially African women carry the burden of providing for

26 It is for example impossible to understand the resilience of the church under apartheid without a deep sense of ecumenical solidarity, i.e. professing the faith in local circumstances as the catholic faith.

27 If 'postmaterialism' (Inglehart) results from people moving out of economic instability where basic needs like food and security have been met (Ward 2009: 81), it would be difficult to apply this to the vast majority of African urbanites. 
families in the absence of men who went to work or to seek for work in the cities). In the city the GDP growth is higher and the poverty levels ${ }^{28}$ lower than in non-urban and rural areas; but here the income inequalities are also more pronounced as one can literally look from the slum onto the riches of the "real" people in the "real" city.

In is in this space that the church as "apostolic" church steps and lives. The tradition teaches us that apostolicity calls the church to hold on to its very foundations in the teachings of the prophets and apostles ${ }^{29}$, reinterpreting those teachings for each age, including for the age of rapid urbanization and solidified urbanism. The church has been and will always be torn between (on the one hand) a fundamentalist, a-historical reading of the Scriptures and (on the other) allowing the Spirit to lead the church in the ever revealing truth of God, reading the signs of the times to speak an apostolic word.

In every age, there was an apostolic expression of the faith as much as there was a false interpretation or even a heresy. The Protestant Reformation with its emphasis on justification by faith alone was a counter-voice of apostolicity that radically altered the history of Western Europe and the church itself. The Barmen declaration (1934), infused by the theologies of Barth, Bonhoeffer and others, was a counter-voice of apostolicity pointing to Jesus Christ as the only Word of God. This witness undermined the theological roots of National-Socialism, leading to the establishment of a confessing church in the midst of the powerful German Christian establishment. The same holds for the Belhar confession (1982) that boldly witnessed against a heretical confirmation of racism and for unity, reconciliation, justice and discipleship.

28 The "poverty rate" varies from country to country and also changes over time. In South Africa this was set at a monthly income below ZAR2 300 in 2014. The poverty rate data on rural districts compared with urban metropolitan areas for South Africa confirm the pattern that - purely in monetary terms - there are a smaller proportion of people living below the poverty line in urban areas, though the actual numbers are much larger and they live in close proximity to those who fall in the 7 - 10 LSM categories, raising the sense and reality of income inequality (IRR 2014: 324-325).

29 "The church is apostolic because everything it confesses about Christ comes from the apostles as witness..." and is now called to follow "the example of the apostles in continuing their mission to proclaim the gospel which is confirmed by the action and gift of the Holy Spirit" (WCC:1991, paragraph 241). 
The hermeneutical angle of understanding the apostolic faith from the perspective of the marginalised and the oppressed people at the underside of history, ${ }^{30}$ living in sub-modernity, has become a shared ecumenical consensus. In remarkably bold fashion, the WCC project, when discussing the suffering solidarity of Christ, states: "In the particular case of human oppression, the victim is assured that God is never on the side of the oppressor, the bringer of death, but will, in his justice, protect the rights and lives of the victims" (paragraph 157).

This is probably the most challenging part of being church in the city: To proclaim and live out the good news - the apostolic message - to the poor, the blind, the captives and the oppressed as inauguration of the year of the Lord (Luke 4). It is the challenge to be present not only as church of and for the poor, but as "poor church" (Sobrino) ${ }^{31}$ with all its ramifications of solidarity with those living on the city margins, whether physically, economically or socially.

It is this lived apostolicity, in the Name of the living Christ, that opposes the self-secularization of the church as just another NGO with a relief mission, thereby superseding the false oppositions between sacred and profane. This kind of apostolicity also challenges the privatization of the faith in both its "personal" and its "public" guises. The latter often raises a public voice on matters of micro-morality ("the gay issue"), but is often blind to the structural dimensions of oppression fed by religious convictions about the second tier status of woman and health/prosperity as necessary signs of God's blessings.

30 The combined effect of European political theologies, Latin American liberation theologies, Black and feminist theologies, as well as a retrieval of justice as key dimension of the Reformed heritage (see e.g. Belhar art. 4), all contributed to this hermeneutical shift. It found its way into political discourse via John Rawls' theory of social justice (Rawls 1972) which takes as reference point "the least advantaged representative man" and - on a global scale - seek preferential treatment for those countries which may be called "burdened societies" (Rawls 1999). For an extensive discussion, read Piet Naudé's article on "partisan" justice (Naudé 2007).

31 Jon Sobrino's well-known work, The true church and the poor (1984), followed the trajectory of his earlier Christological works and radically shifts the point of departure for ecclesiology to the poor. In March 2007 he was the subject of a theological notification from the Vatican via the Congregation for the Doctrine of the Faith for moving the primary ecclesial setting of the church from the apostolic faith as transmitted through all generations to the situation of the poor. 


\section{The weakness of the urban church}

The marks of the church are not empirical descriptions of the church. These marks will always only be partially realised and will always express the fundamental ambiguity of the Christian faith community which is at the same time justified and sinful. Therefore the church will always be one in disunity, un-holy in holiness, inward-looking in its catholicity, and unfaithful to its apostolic calling.

It is worthwhile to listen to Karl Barth in this regard:

"It may well happen that we might want to drop the hand that is put to the plough, when we compare the Church with its goal. We may often have a distaste for the whole of Church life. If you do not know this oppression; if you simply feel well inside the Church's walls, you have certainly not seen the dynamics in this matter... Something bigger (the realization of the kingdom) is at stake here than our bit of preaching and liturgy!” (Barth 1949: 147).

The notae ecclesia are statements of faith, love and, above all, hope-inaction $^{32}$, and assist us to confess and live who Jesus Christ is for urbanites today. The marks are powerful metaphors and practices that can reciprocally shape the church and the city to establish first fruits of the city not built by human hands, but promised by God as a gift to all creatures.

In the meantime the church remains connected to the crucified Christ and despite its own weakness and "pettiness" (Barth), accepts that "the foolishness of God is wiser than men, and the weakness of God is stronger than men... He who glories, let him glory in the Lord" (1 Cor. 1).

\section{References}

Barth, Karl 1949. Dogmatics in outline. London: SCM.

Boesak, Allan and Hansen Len (eds.) 2009. Globalization - The politics of empire, justice and the life of faith. Stellenbosch: Sun Press.

Boesak, Allan and Hansen, Len (eds.) 2010. Globalization II: Global crisis, global challenge, global faith. Stellenbosch: Sun Press.

32 "Faith, hope and action are the genesis of the form of the church, visible to the world in unity, holiness, catholicity and apostolicity" (Moltmann 1977:340). For a discussion of the marks of the church in dialogue with Moltmann, read Naudé 2006. 
Chabal, P 2009. Africa: The politics of suffering and smiling. London: Zed Books.

Church of England (Commission on urban priority areas) 1985. Faith in the city. A call to action for church and nation. London: Church House publishing.

Cloete, Daan G and Smit, Dirk J 1984. A moment of truth. The confession of the Dutch Reformed Mission Church 1982. Grand Rapids: Eerdmans.

De Gruchy, John 1979. The church struggle in South Africa. Cape Town: David Philip.

Held, David, McGrew, Anthony, Goldblatt, David \& Perraton, Jonathan 1999. Global transformations. Politics, economy and culture. Stanford: Stanford University Press.

Long, N 2001. Development Sociology. Actor perspectives. London: Routledge.

Mbiti, John 1969. African religions and philosophy. London: Heinemann.

Moltmann, Jürgen 1977. The church in the power of the Spirit. London: SCM.

Naudé, Piet 2006. The marks of the church in South Africa today. In dialogue with Jürgen Moltmann on his 80th birthday. Verbum et Ecclesia 27/3, 944-963.

Naudé, Piet 2007. In defence of partisan justice? An ethical reflection on "the preferential option for the poor". Verbum et Ecclesia 28/1, 166-190.

Naudé, Piet 2010. Neither calendar nor clock. Perspectives on the Belhar confession. Grand Rapids: Eerdmans.

Naudé, Piet 2011. Is prophetic discourse adequate to address global economic justice? HTS Teologiese Studies/Theological Studies 67 (1) Art. \#1014, 8 pages. DOI: 10.4102/hts.v67i1.1014.

Naudé, Piet 2011. “Am I my brother’s keeper?” An African reflection on humanization. In Len Hansen, Nico Koopman \& Robert Vosloo (eds.): Living theology. Essays presented to Dirk J Smit on his sixtieth birthday. Wellington: Bible Media, 496-512.

Patel, Raj 2011. The value of nothing. London: Portobello. 
Pieterse, Edgar \& Simone, AbdouMaliq 2013. Rogue urbanism. Emergent African cities. Cape Town: Jacana.

Pieterse, Edgar 2010. Cityness and African urban development. Urban Forum 21(3), 289-300.

Pieterse, Edgar 2013a. Grasping the unknowable: Coming to grips with African urbanisms. In Pieterse and AbdouMaliq, 19-35

Pieterse, Edgar 2013b. Introducing rogue urbanism. In Pieterse and AbdouMaliq, 12-15.

Ralws, John 1972. A theory of justice. Cambridge, Mass.: Harvard University Press

Ralws. John 1999. The law of peoples. Cambridge, Mass.: Harvard University Press.

Schlink, Edmund 2005. Schriften zu Ökumene und Bekenntnis. Band 2. Ökumenische Dogmatik. Göttingen: Vandenhoeck \& Ruprecht.

South African Institute of Race Relations (SAIRR) 2014. South Africa survey 2014/2015. Johannesburg: IRR.

Smit, Dirk J 2007. Essays in public theology. Collected essays I. Stellenbosch: Sun Press.

Smit, Dirk J 2008. Oor die kerk as unieke samelewingsverband. In Geloof en openbare lewe. Versamelde opstelle 2. Stellenbosch: Sun Press, 69-82.

Sobrino, Jon 1984. The true church and the poor. London: SCM.

Stackhouse, Max L 2009. God and globalization. Volume 4: Globalization and grace. New York: Continuum.

Ward, Graham 2009. The politics of discipleship. Becoming postmaterial citizens. Grand Rapids: Baker Academic.

WCC 1991. Confessing the one faith. The ecumenical explication of the Apostolic faith as it is confessed in the Nicene-Constantinopolitan Creed (381). Faith and Order Paper No 153. Geneva: WCC. 